\title{
The Influence of Product Quality and Service Quality on Customer Satisfaction at Mitra 10 in Depok
}

\author{
Neneng Susanti ${ }^{1}$, Jasmani $^{2}$ \\ ${ }^{1}$ Universitas Widyatama \\ ${ }^{2}$ Universitas Pamulang \\ E-mail: neneng.susanti@widyatama.ac.id
}

\begin{abstract}
This study aims to determine the effect of product quality and service quality on customer satisfaction at Mitra 10 in Depok. The method used was explanatory research with a sample of 96 respondents. The analysis technique uses statistical analysis with regression testing, correlation, determination, and hypothesis testing. The results of this study product quality have a significant effect on customer satisfaction by $41.6 \%$, hypothesis testing obtained significance $0,000<0.05$. Service quality has a significant effect on customer satisfaction by $42.7 \%$, hypothesis testing obtained significance 0,000 $<0.05$. Product quality and service quality simultaneously have a significant effect on customer satisfaction by $52.3 \%$, hypothesis testing obtained significance of $0,000<0.05$.
\end{abstract}

Key words: Product quality, service quality, customer satisfaction.

\section{INTRODUCTION}

The size of retail business opportunities in Indonesia has spurred foreign retail companies into (Dwi Suhartanto, Tjetjep Djatnika, Ruhardi, 2017; Imtiyaz, Nasrun, \& Ahmad, 2015; Soliha, 2008; Sulmiah, 2017; Utomo, 2011). The entry of foreign entrepreneurs in this business shows that this business is very profitable. Although on the other hand, it is certainly a competitor for local players. However, modern markets are needed. Times have changed, so they must be ready to enter these changing times, including addressing the presence and competition in this modern market (Kotler \& Keller, 2009; Pandin, 2009; Sarwoko, 2008). Therefore, change must be faced as a service quality to improve quality in providing the best to consumers. In big cities in Indonesia, hypermarts, Dept. Stores and Minimarkets keep popping up. This stretching can be observed in one of the largest building materials department stores, PT. Catur Mitra Sejati Sentosa (Mitra10) which continues to build outlets in various cities in Indonesia.

The increasing intensity of competition and the number of competitors requires companies to always pay attention to the needs and desires of consumers and try to meet consumer expectations by providing more satisfying services than those carried out by competitors. Thus, only quality companies can compete and dominate the market. The purpose of a business is to create satisfied customers (Sugiati, Thoyib, Hadiwidjoyo, \& Setiawan, 2013). Superior and consistent service quality can grow customer satisfaction and will provide various benefits. Customer satisfaction is the customer's response to the discrepancy between the level of interest 


\author{
76| Jurnal Office: Jurnal Pemikiran Ilmiah dan Pendidikan Administrasi Perkantoran \\ Vol. 5, No. 2, July-December 2019, Hal 75-84
}

before and the actual performance felt after use. Customer satisfaction is influenced by perceptions of service quality, product quality, customer value and factors that are personal as well as those of a momentary situation (Agtovia Frimayasa, 2017; Aryani \& Rosinta, 2010; Brata, 2003).

Quality has a close relationship with customer satisfaction (Artiningtyas, Minarsih, \& Hasiolan, 2014; Ghozali, 2014; Rohaeni \& Marwa, 2018). Quality provides an impetus for customers to forge strong ties with the company. In the long run, this kind of bond allows the company to carefully understand customer expectations and their needs. Thus, the company can increase customer satisfaction where the company maximizes a pleasant customer experience and minimizes a less pleasant customer experience. Products become an important instrument for achieving success and prosperity in a modern company (Anggriawan \& Brahmayanti, 2016; Ariani, 2016). Technological development, increasing global competition, and market needs and desires require companies to develop products continuously. There are only two choices, namely success in product development so that it produces a superior product, or fails in achieving its business goals because the product is not able to compete in the market.

A product can satisfy consumers when viewed can meet or exceed their desires and expectations (Bilgies, 2017; Ghozali, 2014; Piri, 2013). Quality is also the most fundamental of customer satisfaction and success in competition. In fact, quality develops quality practices and shows consumers that they are able to find increasingly high-quality expectations. Product quality can be interpreted as the ability of a product to carry out its functions includes: product performance, durability, reliability, accuracy, ease of operation and repair, as well as other valuable attributes.

Besides that, the dimension of product quality is also an important factor, because, with the current condition, quality products have more value than competing products. Quality is the totality of features and characteristics of a product or service that depends on its ability to satisfy stated or implied needs (Keller, 2007; Kotler \& Keller, 2009)

\title{
METHOD
}

The type of research used is associative, where the aim is to find out the relationship between variables. The population in this study amounted to 96 Mitra 10 respondents in Depok. The sampling technique in this study is saturated sampling, where all members of the population are sampled. Thus the sample in this study amounted to 96 respondents. In analyzing the data used the instrument test, classical assumption test, regression, coefficient of determination and hypothesis testing.

\section{RESULT AND DISCUSSION}

Customer satisfaction is the customer's perception of service quality that focuses on five dimensions of service quality, namely: tangibles, reliability, responsiveness, assurance, and empathy. If Mitra10 is not consistent in providing the best service and products to consumers, consumers will move to other places to meet their needs. From the problems above are 
important points in maintaining company sustainability, mistakes in managing complaints, it is not impossible that Mitra10 Depok will be left by its customers. therefore companies are required to provide excellent and quality service. Service quality standards must be applied in order to achieve the expected goals. In addition, the company is also required to satisfy customers by providing appropriate services and products that add value to customers.

\section{Descriptive Analysis}

This test used to determine the highest minimum and maximum scores, ratting scores and standard deviations of each variable. The results are as follows:

Table 1.

Descriptive Statistics Analysis Results

Descriptive Statistics

\begin{tabular}{lr|r|r|r|r}
\hline & N & Minimum & Maximum & Mean & Std. Deviation \\
\hline Product Quality (X1) & 96 & 32 & 48 & 38.50 & 3.874 \\
\hline Quality of Service (X2) & 96 & 30 & 45 & 38.46 & 3.676 \\
\hline Customer Satisfaction (Y) & 96 & 32 & 46 & 39.20 & 3.541 \\
\hline Valid N (listwise) & 96 & & & & \\
\hline
\end{tabular}

Product quality obtained a minimum variance of 32 and a maximum variance of 48 with a rating score of 3.85 with a standard deviation of 3.874. Quality of service obtained a minimum variance of 30 and a maximum variance of 45 with a rating score of 3.85 with a standard deviation of 3.676. Customer satisfaction obtained a minimum variance of 32 and a maximum variance of 46 with a rating score of 3.92 with a standard deviation of 3.541 .

\section{Multiple Regression Analysis}

This regression test is intended to determine changes in the dependent variable if the independent variable changes. The test results are as follows:

Table 2

Multiple Regression Testing Results

\section{Coefficients $^{\mathbf{a}}$}

Unstandardized

Coefficients

\begin{tabular}{|c|c|c|c|c|c|}
\hline Model & B & Std. Error & Beta & $\mathrm{t}$ & Sig. \\
\hline 1 (Constant) & 10.084 & 2.896 & & 3.482 & .001 \\
\hline Product Quality (X1) & .358 & .083 & .392 & 4.324 & .000 \\
\hline Quality of Service (X2) & .399 & .087 & .414 & 4.572 & .000 \\
\hline
\end{tabular}

a. Dependent Variable: Costumer Satisfaction (Y) 


\section{8 | Jurnal Office: Jurnal Pemikiran Ilmiah dan Pendidikan Administrasi Perkantoran Vol. 5, No. 2, July-December 2019, Hal 75-84}

Based on the test results in the above table, the regression equation $\mathrm{Y}=10.084+0.358 \mathrm{X} 1+$ $0.399 \mathrm{X} 2$ is obtained. A constant of 10,084 means that if the product quality and service quality does not exist, then there is a customer satisfaction value of 10,084 points. Product quality regression coefficient of 0.358 , this number is positive meaning that every time there is an increase in product quality by 0.358 , customer satisfaction will also increase by 0.358 points. Service coefficient regression coefficient of 0.399 , this number is positive meaning that every time there is an increase in service quality of 0.399 , customer satisfaction will also increase by 0.399 points.

\section{Correlation Coefficient Analysis}

Correlation coefficient analysis is intended to determine the degree of relationship strength of the independent variables on the dependent variable either partially or simultaneously. The test results are as follows:

Table 3 .

Correlation Coefficient Testing Results Product Quality Against Customer Satisfaction Correlations $^{\mathbf{b}}$

\begin{tabular}{|c|c|c|c|}
\hline & & $\begin{array}{l}\text { Product Quality } \\
\text { (X1) }\end{array}$ & $\begin{array}{c}\text { Customer } \\
\text { Satisfaction (Y) }\end{array}$ \\
\hline \multirow[t]{2}{*}{$\overline{\text { Product Quality (X1) }}$} & Pearson Correlation & 1 & $.645^{* *}$ \\
\hline & Sig. (2-tailed) & & .000 \\
\hline \multirow[t]{2}{*}{ Customer Satisfaction (Y) } & Pearson Correlation & $.645^{* *}$ & 1 \\
\hline & Sig. (2-tailed) & .000 & \\
\hline
\end{tabular}

**. Correlation is significant at the 0.01 level (2-tailed).

b. Listwise $\mathrm{N}=96$

Based on the test results obtained a correlation value of 0.645 means that product quality has a strong relationship to customer satisfaction. 
Table 4.

Correlation Coefficient Testing Results Service Quality Against Customer Satisfaction.

Correlations $^{\mathbf{b}}$

\begin{tabular}{llr|r}
\hline & & $\begin{array}{c}\text { Quality of } \\
\text { Service (X2) }\end{array}$ & $\begin{array}{c}\text { Customer } \\
\text { Satisfaction (Y) }\end{array}$ \\
\hline Quality of Service (X2) & Pearson Correlation & 1 & $.654^{* *}$ \\
\cline { 2 - 4 } & Sig. (2-tailed) & $.654^{* *}$ & .000 \\
\hline Customer Satisfaction (Y) & Pearson Correlation & .000 & 1 \\
\cline { 2 - 4 } & Sig. (2-tailed) & & \\
\hline
\end{tabular}

**. Correlation is significant at the 0.01 level (2-tailed).

b. Listwise $\mathrm{N}=96$

Based on the test results obtained by the correlation value of 0.654 means that service quality has a strong relationship to customer satisfaction.

Table 5.

Test Results Correlation Coefficient Product Quality and Service Quality Simultaneously on Customer Satisfaction.

Model Summary

\begin{tabular}{lrr|rrr}
\hline Model & & \multicolumn{2}{c}{$\begin{array}{c}\text { Adjusted R } \\
\text { Square }\end{array}$} & $\begin{array}{c}\text { Std. Error of the } \\
\text { Estimate }\end{array}$ \\
\hline 1 & $\mathrm{R}$ & R Square & .523 & .513 & 2.472 \\
\hline
\end{tabular}

a. Predictors: (Constant), Quality of Service (X2), Product Quality (X1)

Based on the test results obtained a correlation value of 0.723 means that product quality and service quality simultaneously have a strong relationship to customer satisfaction.

\section{Analysis of the Coefficient of Determination}

Analysis of the coefficient of determination is intended to determine the percentage of influence of the independent variable on the dependent variable either partially or simultaneously. The test results are as follows:

Table 6

Test Results for the Determination Coefficient of Product Quality on Customer Satisfaction.

Model Summary

\begin{tabular}{lrr|rr|r}
\hline Model & & \multicolumn{2}{c|}{$\begin{array}{c}\text { Adjusted R } \\
\text { Square }\end{array}$} & $\begin{array}{c}\text { Std. Error of the } \\
\text { Estimate }\end{array}$ \\
\hline 1 & $\mathrm{R}$ & \multicolumn{1}{c|}{ R Square } & \multicolumn{2}{c}{ Squar } \\
\hline
\end{tabular}

a. Predictors: (Constant), Product Quality (X1) 


\section{0| Jurnal Office: Jurnal Pemikiran Ilmiah dan Pendidikan Administrasi Perkantoran \\ Vol. 5, No. 2, July-December 2019, Hal 75-84}

Based on the test results obtained a determination value of 0.416 means that product quality has an influence contribution of $41.6 \%$ on customer satisfaction.

Table 7

Determination Coefficient Test Results Service quality on customer satisfaction.

Model Summary

\begin{tabular}{lr|rr|r}
\hline Model & R & R Square & $\begin{array}{c}\text { Adjusted R } \\
\text { Square }\end{array}$ & $\begin{array}{c}\text { Std. Error of the } \\
\text { Estimate }\end{array}$ \\
\hline 1 & $.654^{\mathrm{a}}$ & .427 & .421 & 2.694 \\
\hline a. Predictors: (Constant), Quality of Service (X2)
\end{tabular}

Based on the test results obtained a determination value of 0.427 means that service quality has an influence contribution of $42.7 \%$ to customer satisfaction.

Table 8.

Test Results Determination Coefficient Product quality and service quality on customer satisfaction

\section{Model Summary}

\begin{tabular}{|c|c|c|c|c|}
\hline Model & $\mathrm{R}$ & R Square & $\begin{array}{l}\text { Adjusted R } \\
\text { Square }\end{array}$ & $\begin{array}{l}\text { Std. Error of the } \\
\text { Estimate }\end{array}$ \\
\hline 1 & $.723^{\mathrm{a}}$ & .523 & .513 & 2.472 \\
\hline
\end{tabular}

a. Predictors: (Constant), Quality of Service (X2), Product Quality (X1)

Based on the test results obtained a determination value of 0.523 means that product quality and service quality simultaneously have an influence contribution of $52.3 \%$ to customer satisfaction, while the remaining $42.7 \%$ is influenced by other factors

\section{Hypotesis Testing}

Hypothesis testing with a t-test is used to find out which partial hypotheses are accepted.

Table 9

Hypothesis Test Results Product quality on customer satisfaction.

\begin{tabular}{|c|c|c|c|c|c|}
\hline \multirow[b]{2}{*}{ Model } & \multicolumn{2}{|c|}{$\begin{array}{l}\text { Unstandardized } \\
\text { Coefficients }\end{array}$} & \multirow{2}{*}{$\begin{array}{c}\text { Standardized } \\
\text { Coefficients } \\
\text { Beta }\end{array}$} & \multirow[b]{2}{*}{$\mathrm{t}$} & \multirow[b]{2}{*}{ Sig. } \\
\hline & B & Std. Error & & & \\
\hline (Constant) & 16.506 & 2.788 & & 5.921 & .000 \\
\hline Product Quality (X1) & .589 & .072 & 645 & 8.181 & .000 \\
\hline
\end{tabular}

a. Dependent Variable: Customer Satisfaction (Y) 
Based on the test results in the table 9 , the value of $t_{\text {count }}>t_{\text {table }}$ or $(8,181>1,661)$ is obtained, thus the first hypothesis proposed that there is a significant influence on product quality on customer satisfaction is accepted.

Table 10.

Hypothesis Test Results Service Quality on Customer Satisfaction.

\section{Coefficients $^{\mathrm{a}}$}

\begin{tabular}{|c|c|c|c|c|c|c|}
\hline \multirow{2}{*}{\multicolumn{2}{|c|}{ Model }} & \multicolumn{2}{|c|}{$\begin{array}{c}\text { Unstandardized } \\
\text { Coefficients }\end{array}$} & \multirow{2}{*}{$\begin{array}{l}\text { Standardized } \\
\text { Coefficients } \\
\text { Beta }\end{array}$} & \multirow[b]{2}{*}{$\mathrm{t}$} & \multirow[b]{2}{*}{ Sig. } \\
\hline & & B & Std. Error & & & \\
\hline \multirow[t]{2}{*}{1} & (Constant) & 14.985 & 2.905 & & 5.158 & .000 \\
\hline & Quality of Service (X2) & .630 & .075 & .654 & 8.373 & .000 \\
\hline
\end{tabular}

a. Dependent Variable: Customer Satisfaction (Y)

Based on the test results in the above table, the value of $t_{\text {count }}>t_{\text {table }}$ or $(8.337>1.661)$ is obtained, thus the second hypothesis is proposed that there is a significant influence between the quality of service on customer satisfaction received.

Hypothesis testing with the F test is used to find out which simultaneous hypotheses are accepted.

Table 11.

Hypothesis Test Results for Product Quality and Service Quality Against Customer Satisfaction.

ANOVA ${ }^{\mathrm{a}}$

\begin{tabular}{llr|r|r|c|c}
\hline & Model & Sum of Squares & \multicolumn{1}{c}{ df } & Mean Square & \multicolumn{1}{c}{ F } & \multicolumn{1}{c}{ Sig. } \\
\hline 1 & 623.119 & 2 & 311.560 & 51.002 & $.000^{\mathrm{b}}$ \\
\hline & & & & & \\
\hline Regression & 568.120 & 93 & 6.109 & & \\
\hline Residual & 1191.240 & 95 & & & \\
\hline Total & & &
\end{tabular}

a. Dependent Variable: Customer Satisfaction (Y)

b. Predictors: (Constant), Quality of Service (X2), Product Quality (X1)

Based on the test results in the above table, the calculated $F_{\text {count }}>F_{\text {table }}$ or $(51.002>2,700)$, thus the third hypothesis proposed that there is a significant influence between product quality and service quality on customer satisfaction received.

\section{CONCLUSION}

Based on the results of the study, product quality has a significant effect on customer satisfaction with an influence contribution of $41.6 \%$. Hypothesis testing obtained $t_{\text {count }}>t_{\text {table }}$ or $(8,181>1,661)$. Service quality has a significant effect on customer satisfaction with a contribution of $42.7 \%$. Hypothesis testing obtained $t_{\text {count }}>t_{\text {table }}$ or $(8.373>1.661)$. Product quality and service quality significantly influence customer satisfaction with a contribution of $52.3 \%$ 
82 Jurnal Office: Jurnal Pemikiran Ilmiah dan Pendidikan Administrasi Perkantoran Vol. 5, No. 2, July-December 2019, Hal 75-84

while the remaining $42.7 \%$ is influenced by other factors. Hypothesis testing obtained by the calculated $\mathrm{F}_{\text {count }}>\mathrm{F}_{\text {table }}$ or $(51.002>2,700)$.

\section{REFERENCES}

Agtovia Frimayasa. (2017). Konsep dasar dan strategi pelayanan prima (Service Excellent). Cakrawala. https://doi.org/10.1016/j.febslet.2007.05.054

Anggriawan, J., \& Brahmayanti, I. A. S. (2016). Keputusan Pembelian Konsumen Di Pt . Finele ( Amala Gold Shop ) Pasar Atom Mall Surabaya. Jurnal Ekonomi \& Bisnis.

Ariani, W. (2016). Manajemen Kualitas. Jurnal Managemen.

Artiningtyas, I., Minarsih, M. M., \& Hasiolan, L. B. (2014). Kepuasan Pelanggan. Pengaruh Kualitas Layanan, Persepsi Harga dan Kepercayaan Terhadap Kepuasan Pelanggan.

Aryani, D., \& Rosinta, F. (2010). Pengaruh Kualitas Layanan terhadap Kepuasan Pelanggan dalam Membentuk Loyalitas Pelanggan. Jurnal Ilmu Administrasi dan Organisasi.

Bilgies, A. F. (2017). Peran Kualitas Produk, Harga Dan Kualitas Layanan Terhadap Kepuasan Pelanggan Billagio Skincare Clinic Sidoarjo. Ekonika: Jurnal ekonomi universitas kadiri. https://doi.org/10.30737/ekonika.v1i1.7

Brata, A. A. (2003). Dasar-Dasar Pelayanan Prima. (Jakarta: PT. Elex Media Komputindo, 2003).

Dwi Suhartanto, Tjetjep Djatnika, Ruhardi, N. N. T. (2017). Ritel Pengelolaan dan Pemasaran. In Alfabeta.

Ghozali, M. (2014). Pengaruh Kualitas Pelayanan Dan Harga Terhadap Kepuasan Pelanggan Pada Expedisi Di Surabaya. Ilmu \& Riset Manajemen.

Imtiyaz, M. Z., Nasrun, M., \& Ahmad, U. A. (2015). Analisis Dan Implementasi Framework Crisp-Dm Untuk Mengetahui Perilaku Data Transaksi Pelanggan. $e$ Proceeding of Engineering.

Keller, K. P. dan. (2007). Manajemen Pemasaran: Analisis, Perencanaan, Implementasi dan Pengendalian. Prentice Hall, Salemba Empat.

Kotler, P., \& Keller, K. L. (2009). Manajemen pemasaran Jilid 1. In Jakarta.

Niswaty, R., Juniati, F., Darwis, M., Salam, R., \& Arhas, S. H. (2019). The Effectiveness of Leadership Functions Implementation in The Makassar 
Departement of Manpower. JPBM (Jurnal Pendidikan Bisnis dan Manajemen), $5(1), 1-10$.

Pandin, M. L. (2009). Potret Bisnis Ritel Di Indonesia: Pasar Modern. Economic Review.

Piri, H. (2013). Kualitas Pelayanan Jasa Pengaruhnya Terhadap Loyalitas Pelanggan Pada Steiner Salon Manado. Jurnal Riset Ekonomi, Manajemen, Bisnis dan Akuntansi.

Rohaeni, H., \& Marwa, N. (2018). Kualitas Pelayanan Terhadap Kepuasan Pelanggan. Jurnal Ecodemica: Jurnal Ekonomi, Manajemen, dan Bisnis. https://doi.org/10.31311/JECO.V2I2.4503

Sarwoko, E. (2008). Dampak Modernisasi Keberadaan Pasar Modern terhadap Pedagang Pasar Tradisional di Wilayah Kabupaten Malang. Jurnal Ekonomi Modernisasi. https://doi.org/10.21067/jem.v4i2.880

Sedarmayanti. (2012). Good Governance: Kepemerintahan Yang Baik \& Good Corporate Governance: Tata Kelola Perusahaan Yang Baik. Bagian Ketiga, Edisi Revisi. Bandung: CV. Bandar Maju. https://doi.org/10.29040/jiei.v4i2.260

Soliha, E. (2008). Analisis Industri Ritel di Indonesia. Jurnal Bisnis dan Ekonomi $(J B E)$.

Sugiati, T., Thoyib, A., Hadiwidjoyo, D., \& Setiawan, M. (2013). The Role of Customer Value on Satisfaction and Loyalty (Study on Hypermart's Customers). International Journal of Business and Management Invention ISSN (Online.

Sulmiah, S. (2017). Perkembangan Pasar Modern di Indonesia dan Dampaknya terhadap Pasar Tradisional. Latihan.

Utomo, T. J. (2011). Persaingan Bisnis Ritel : Tradisional vs Modern (The Competition of Retail Business : Traditional vs Modern). Fokus Ekonomi. 
84| Jurnal Office: Jurnal Pemikiran Ilmiah dan Pendidikan Administrasi Perkantoran Vol. 5, No. 2, July-December 2019, Hal 75-84 